\title{
Relating Transient Storage and WhOLE-System METABOLISM WITH NITROGEN UPTAKE IN STREAMS
}

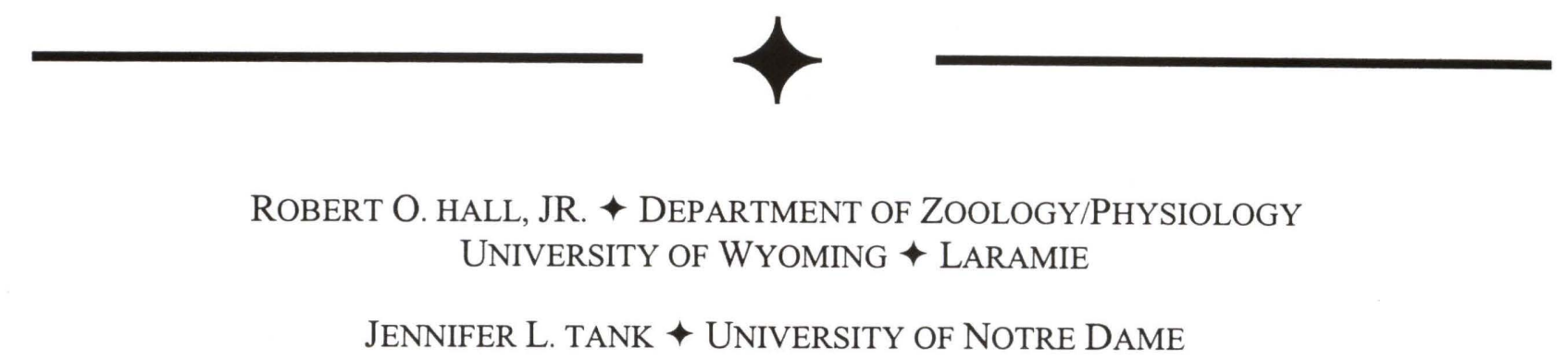

\section{$\downarrow \quad$ INTRODUCTION}

Streams are important landscape features because they provide an avenue for nitrogen loss from a watershed to downstream ecosystems and eventually the ocean; however, in-stream processes can control nutrient transport and export (e.g. Burns 1998). Nitrogen is an important element because it limits rates of primary production in many terrestrial and aquatic ecosystems. Alteration of the forms, timing, and concentration of nutrients is a central property of lotic systems (Fisher et al. 1998). Understanding controls on both transport and retention are central to predicting how streams influence nutrient loss from watersheds (Hedin et al. 1995, Likens and Bormann 1995, Burns 1998) and nutrient loading to downstream ecosystems (Howarth et al. 1996). With increased global nutrient loading from atmospheric sources and fertilizers, streams may play an important role in the retention, transformation and export of nutrients from the upland landscape.

We know little about what controls nutrient uptake and transport in streams. There are many studies that show effects of hydrologic, biologic, and geomorphic influences on nutrient transport, but rarely have all aspects been considered in the same study. One potentially important geomorphic control is transient storage. Transient storage is water that is separated from the main channel flow and therefore, moves downstream more slowly than water in the main stream channel, which should facilitate nutrient uptake. Transient storage has been suggested to play an important role in nutrient retention in streams from both theoretical (Mulholland and DeAngelis 2000) and empirical perspectives (Valett et al. 1996, Mulholland et al. 1997). Additionally no studies have linked whole stream measures of metabolism with stream nutrient uptake, though we expect that greater $C$ fixation or respiration will cause higher demand for nutrients.

The objective of our study was to relate nutrient uptake with geomorphic and whole stream metabolism in 8 streams in Grand Teton National Park.

\section{$\downarrow \quad$ STUDY SITES}

We chose 8 streams within GTNP that ranged in size water chemistry and morphology (Table 1). Six streams were in the eastern part of the park and had sedimentary watersheds while 2 (Moose Rd. Creek, N. Moran Bay Creek) were on the Teton Range.

\section{$\downarrow$ METHODS}

To measure nitrogen transport and retention in streams, we used short-term (1-3 hours) additions of nitrate and ammonium in conjunction with a conservative tracer as described in the Stream Solute Workshop (1990) and Webster and Ehrman (1996). Briefly, after collecting background samples of stream solute concentrations, a release solution of a 


\begin{tabular}{|c|c|c|c|c|c|c|c|c|c|}
\hline Stream & $\begin{array}{c}\mathrm{Q} \\
(\mathrm{L} / \mathrm{s})\end{array}$ & $\begin{array}{c}\text { Width } \\
\text { (m) }\end{array}$ & $\begin{array}{l}\text { Velocity } \\
(\mathrm{m} / \mathrm{min})\end{array}$ & K1/K2 & $\begin{array}{l}\text { GPP mg } \\
\mathrm{O}_{2} / \mathrm{m}^{2} / \mathrm{d}\end{array}$ & $\begin{array}{c}\text { Comm. } \\
\text { Resp. mg } \\
\mathrm{O}_{2} / \mathrm{m}^{2} / \mathrm{d} \\
\end{array}$ & $\begin{array}{c}\mathrm{NH}_{4} \\
\text { (ug/l) }\end{array}$ & $\begin{array}{l}\mathrm{NO}_{3} \\
\text { (ug/l) }\end{array}$ & $\begin{array}{c}\text { Total N } \\
\text { uptake } \\
\left.\text { (ug/m } / \mathrm{m}^{2} / \mathrm{d}\right) \\
\end{array}$ \\
\hline Pilgrim Cr. \#1 & 46.2 & 4.1 & 12.1 & 0.21 & 0.24 & 0.97 & 0.5 & $\mathbf{0}$ & 1.2 \\
\hline Pilgrim Cr. \#2 & 12.2 & 2.5 & 6.9 & 0.13 & 0.12 & 1.59 & 0.5 & 0 & 1.0 \\
\hline Ditch Creek & 231.7 & 5.8 & 12.8 & 0.30 & 1.86 & 6.45 & 2.2 & $\mathbf{0}$ & 21.1 \\
\hline Two Ocean Cr. & 144 & 4.1 & 17.7 & 0.18 & 1.37 & 8.77 & 3.3 & 9.9 & 27.3 \\
\hline Lizard Cr. & 25 & 2.5 & 5.6 & 0.22 & 0.46 & 4.10 & 0.9 & 5.5 & 3.7 \\
\hline Bailey $\mathrm{Cr}$. & 117.5 & 5.4 & 12.4 & 0.14 & 2.28 & 2.69 & 1.6 & 5.2 & 11.5 \\
\hline Moose Rd. Cr. & 34.5 & 2.2 & 11.2 & 0.05 & 0.11 & 6.05 & 10.4 & 91 & 11.0 \\
\hline N. Moran Bay & 9 & 0.8 & 4.7 & 0.15 & 0.32 & 5.76 & 1.8 & 43 & 3.4 \\
\hline
\end{tabular}

conservative tracer $(\mathrm{Cl}$ as $\mathrm{NaCl})$ and a nutrient $(\mathrm{N}$ as ammonium or nitrate) was pumped steadily into the stream. Chloride concentration was measured continuously as an increase in conductivity using a conductivity meter. When chloride concentration was constant over time at the downstream end of the 100m study reach, 2 replicate water samples were taken at each of 8 sites spaced along the study reach. Samples were analyzed for nutrient concentrations in the laboratory. Mean nutrient concentrations at each site were divided by chloride concentrations to correct for nutrient decreases caused by downstream increases in discharge rather than nutrient uptake. Nutrient uptake lengths were calculated as the inverse of the slope obtained by regressing log (nutrient/chloride) vs. distance downstream from release site (Stream Solute Workshop 1990, Newbold 1981). We considered both uptake length of nutrient and the uptake velocity of nutrient uptake as our dependent variables. Uptake velocity corrects for the effect of velocity and depth which are primary determinants of nutrient uptake length (Butturini and Sabater 1998, Hall and Bernhardt unpublished data).

We measured transient storage zone size by adding a conservative tracer to the stream concurrent with the nutrient additions as described above. We used chloride (as $\mathrm{NaCl}$ ) as the conservative tracer because it is non-toxic and easy to detect in streamwater using conductivity meters. $\mathrm{Cl}$ concentrations were increased $10 \mathrm{mg} \mathrm{Cl} / \mathrm{L}$. The time series of conductivity measurements from downstream were compared to output of a onedimensional advection, dispersion, and transient storage model (e.g. Bencala and Walters 1983, D'Angelo et al. 1993). Output parameters are $k_{1}$ $(1 / \mathrm{min})$, the rate at which water enters transient storage, and $\mathrm{k}_{2}$, the rate at which water leaves transient storage. Relative size of the transient storage zone $\left(\mathrm{k}_{1} / \mathrm{k}_{2}\right)$ can be considered as the amount of time water spends in transient storage relative to the amount of time water spends in the channel.

Whole-stream metabolism measurements were made by measuring oxygen concentrations at 5 min intervals at the top and bottom of each study reach using Hydrolab recording oxygen meters. We calculated instantaneous metabolism based on differences in oxygen concentrations (upstream vs. downstream) while accounting for the reaeration flux of oxygen with the atmosphere (Marzolf et al. 1994). By integrating these measurements during a continuous 36-h period, we estimated community respiration and gross primary productivity. We estimated the reaeration coefficient by adding sulfur hexafluoride $\left(\mathrm{SF}_{6}\right)$, a non-reactive, non-toxic gas that is useful for tracer applications in water. We performed the trace gas addition concurrently with one of the nutrient additions and use the conservative salt tracer to correct for dilution of the gas by groundwater influx. Reaeration coefficients for oxygen were calculated according to Wanninkhof et al. (1990) and metabolism calculations were based on Marzolf et al. (1994) using the corrected measure of oxygen flux via reaeration (Young and Huryn 1998, Marzolf et al. 1998).

\section{$\uparrow \quad$ RESUlTS AND DiscUSSION}

The 8 streams varied widely in physical and biological attributes (Table1), particularly gross primary production and community respiration which varied 20-fold and 9-fold respectively, suggesting that biological processes varied strongly despite the close proximity of these streams. Transient storage varied about 6-fold, though the values were low relative to some other western montane streams (Valett et al, 1996). Ammonium uptake velocity was higher than nitrate in all streams, which was expected 
because reducing nitrate uses more energy than taking up ammonium (Fig.1).
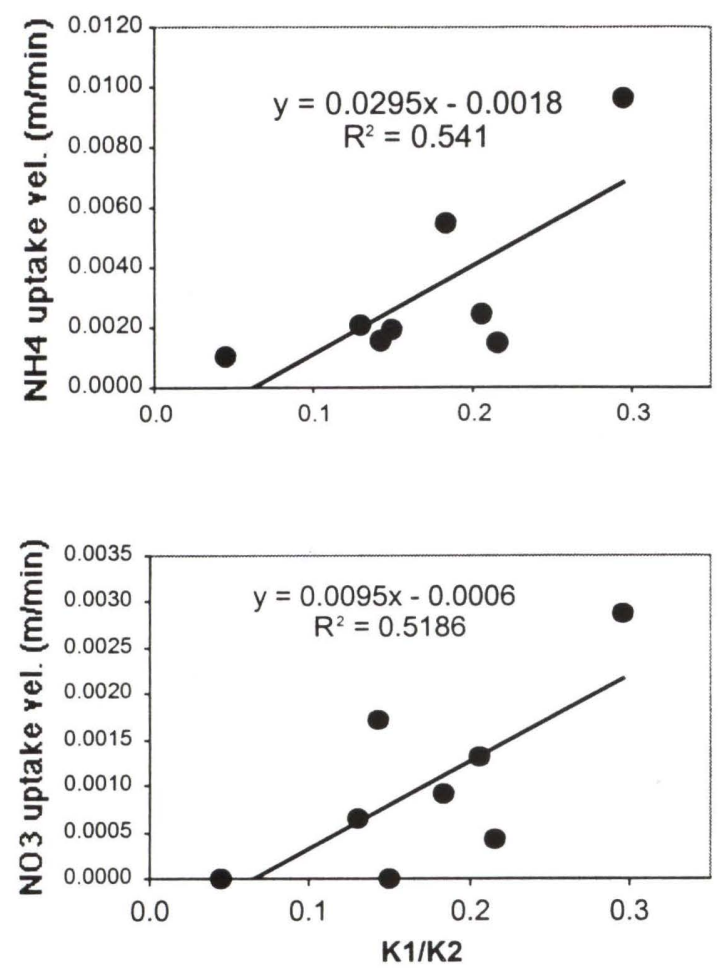

Figure 1. Relationships between transient storage $\left(k_{l} / k_{2}\right)$ and NH4 or NO3 uptake velocity for 8 streams in Grand Teton National Park.

Ammonium and nitrate uptake velocity were weakly related to transient storage, which explained about $50 \%$ of the variation in each. A much better predictor of uptake velocities was gross primary productivity. Respiration appeared to not be a useful predictor of either ammonium or nitrate uptake velocity (Fig 2). However, when considered together, GPP and CR can explain $87 \%$ of nitrate uptake velocity by using multiple regression. Interestingly, $\mathrm{CR}$ does explain ammonium uptake velocities, but only when considered with nitrate concentrations $(\mathrm{R} 2=0.83)$, because streams with high nitrate had low ammonium demand. We presume that high nitrate concentrations alleviates demand for ammonium, which is a pattern observed at Hubbard Brook, NH.

The production/respiration ratios were strongly related to the ratio of nitrate uptake velocity and ammonium uptake velocity (Fig 3 ). This pattern shows that streams with high production (i.e. autotrophic algae) are removing nitrate, while streams with high respiration (i.e. heterotrophic bacteria) are removing ammonium. Algae are likely to be poorer competitors for ammonium than nitrate and therefore use of nitrate are likely. This finding suggests that the type of organisms in a stream (algae vs heterotrophic bacteria) may fundamentally cycle nitrogen differently.
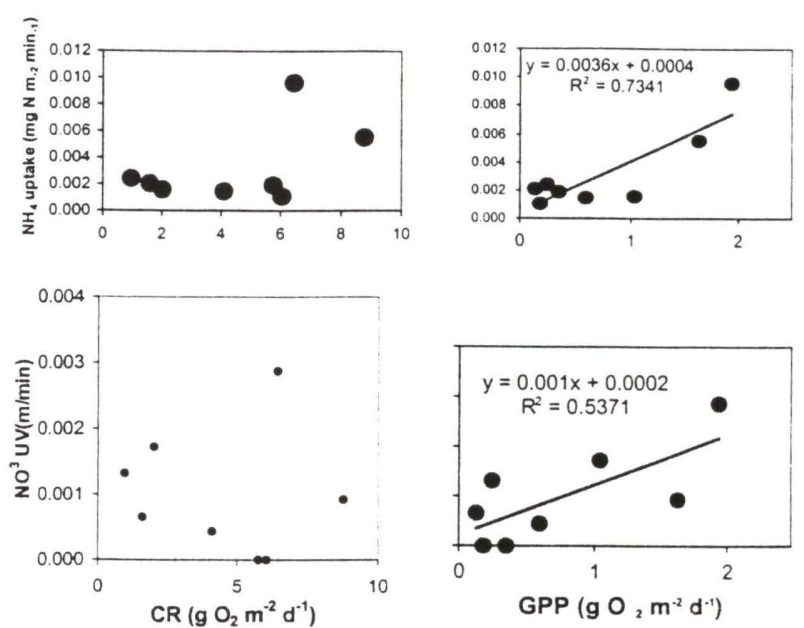

Figure 2. Relationships between metabolism and nutrient uptake in 8 streams in Grand Teton National Park.

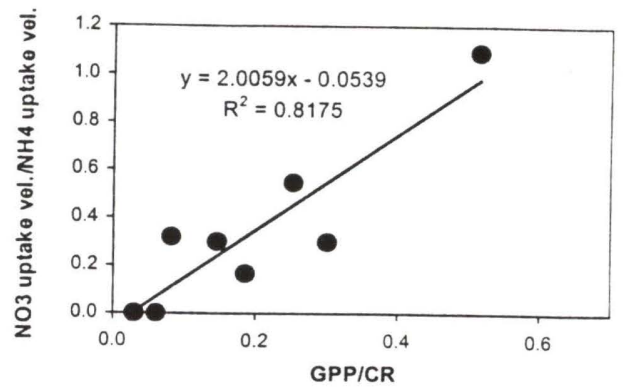

Figure 3. Relationship of production/respiration vs nitrate uptake velocity / ammonium uptake velocity.

These data are the first to statistically link whole-stream estimates of metabolism with nutrient cycling (Mulholland et al. 1997 used only 2 streams), and we show that biotic processes can explain nearly all of the variation in nutrient uptake. Although streams move nutrients from one ecosystem to another, one of their fundamental properties is to alter the timing and form of nutrient delivery. Our study shows that biotic processes within the stream are likely responsible for $\mathrm{N}$ uptake and retention. We suggest that alteration of biotic assemblages would then alter nutrient transport. Our future research for this study will add more streams to this study and examine patterns of nutrient limitation (nitrogen vs phosphorus) in each stream. We also are examining nitrogen concentrations along stream gradients to estimate how streams are net removers of nitrate. 


\section{ACKNOWLEDGEMENTS}

We thank Mike Marshall and Kelly Gordon who assisted with fieldwork. Mike taught us all we know about ammonium analyses. This research was supported by a grant from the UW/NPS field station and a Basic Research Grant from the college of Arts and Sciences, University of Wyoming.

\section{$\uparrow$ REFERENCES}

Bencala, K. E. and R. A. Walters. 1983. Simulation of solute transport in a mountain pool-andriffle stream - a transient storage model. Water Resources Research 19:718-724.

Burns, D. A. 1998. Retention of $\mathrm{NO}_{3}{ }^{-}$in an upland stream environment: a mass balance approach. Biogeochemistry 40:73-96.

Butturini, A. and F. Sabater. 1998. Ammonium and phosphate retention in a Mediterranean stream: hydrological vs. temperature control. Canadian Journal of Fisheries and Aquatic Science 55:1938-1945.

D'Angelo, D. J., J. R. Webster, S. V. Gregory, and J. L. Meyer. 1993. Transient storage in Appalachian and Cascade mountain streams as related to hydraulic characteristics. Journal of the North American Benthological Society 12:223-235.

Fisher, S. G., N. B. Grimm, E. Martí, R. M. Holmes, and J. J. Jones. 1998. Material spiraling in stream corridors: a telescoping ecosystem model. Ecosystems 1:19-34.

Hall, R. O., E. S. Bernhardt, and G. E. Likens. Relating transient storage and nutrient uptake in forested mountain streams Limnology and Oceanography (In Press).

Hedin, L. O., J. J. Armesto, and A. H. Johnson. 1995. Patterns of nutrient loss from unpolluted, old-growth temperate forests: evaluation of biogeochemical theory. Ecology 76:493509.
Howarth, R. W., G. Billen, D. Swaney, A. Townsend, N. Jaworski, K. Lajtha, J. A. Downing, R. Elmgren, N. Caraco, T. Jordan, F. Berendse, J. Freney V. Kudeyarov, P. Murdoch, and Zhu-Zhao-Liang 1996. Regional nitrogen budgets and riverine $\mathrm{N}$ and $\mathrm{P}$ fluxes for the drainages to the North Atlantic Ocean: natural and human influences. Biogeochemistry 35: 75-139.

Likens, G. E., F. H. Bormann, N. M. Johnson, D. W. Fisher, and R. S. Pierce. 1970. The effect of forest cutting and herbicide treatment on nutrient budgets in the Hubbard Brook watershed-ecosystem. Ecological Monographs 40:23-47.

Marzolf, E. R., Mulholland, P.J., and A. D. Steinman. 1994. Improvements to the diurnal upstream-downstream dissolved oxygen change technique for determining wholestream metabolism in small streams. Canadian Journal of Fisheries and Aquatic Sciences 51:1591-1599.

Marzolf, E. R., Mulholland, P.J., and A. D. Steinman. 1998. Reply: Improvements to the diurnal upstream-downstream dissolved oxygen change technique for determining wholestream metabolism in small streams. Canadian Journal of Fisheries and Aquatic Sciences 55:1786-1787.

Mulholland, P. J. and D. L. DeAngelis. 2000. Surface-subsurface exchange and nutrient spiraling. Pages 149-166 in J. B. Jones and P. J. Mulholland, editors. Streams and groundwaters. Academic Press, San Diego.

Mulholland, P. J., E. R. Marzolf, J. R. Webster, D. R. Hart, and S. P. Hendricks. 1997. Evidence that hyporheic zones increase heterotrophic metabolism and phosphorus uptake in forest streams. Limnology and Oceanography 42:443-451.

Newbold, J. D., J. W. Elwood, R. V. O'Neill and W. VanWinkle. 1981. Measuring nutrient spiralling in streams. Canadian Journal of Fisheries and Aquatic Sciences 38: 860-863. 
Stream Solute Workshop. 1990. Concepts and methods for assessing solute dynamics in stream ecosystems. Journal of the North American Benthological Society 9:95-119.

Valett, H. M., J. A. Morrice, C. M. Dahm, and M. E. Campana. 1996. Parent lithology, surfacegroundwater exchange, and nitrate retention in headwater streams. Limnology and Oceanography 41:333-345.
Webster, J. R., and T. P. Ehrman. 1996. Solute dynamics. In F. R. Hauer and G. A. Lamberti, editors. Methods in stream ecology. Academic, San Diego.

Young, R. G. and A. D. Huryn. 1998. Comment: Improvements to the diurnal upstreamdownstream dissolved oxygen change technique for determining whole-stream metabolism in small streams. Canadian Journal of Fisheries and Aquatic Sciences 55:1784-1785. 